\title{
On Zonal Asymmetries in the Heat Budget of the Tropical Oceans
}

\author{
By Stefan Hastenrath \\ The University of Wisconsin, Wisconsin, USA \\ (Manuscript received 4 September 1976, in revised form 26 January 1977)
}

\begin{abstract}
The oceanic heat budget is calculated by conventional methods from ship observations in the Tropical Atlantic and Eastern Pacific during 1911-70. Zonal asymmetries between the Eastern and Western part of the oceans are studied at the examples of the warm Gulf Stream and Brazil, and the cold Canary, Benguela, and Humboldt Current domains. For the same latitude belt, the Canary Current area has a smaller latent heat flux and performs an export of energy to other parts of the globe of $39 \mathrm{~W} \mathrm{~m}^{-2}$ in the annual mean as compared to an import of $43 \mathrm{~W} \mathrm{~m}^{-2}$ in the Gulf Stream region. Off the Pacific coasts of Peru and Chile and the coasts of Southwest Africa, net radiation is reduced by extensive cloudiness, and latent and sensible heat fluxes are also comparatively small. Residual heat export within the oceanic water body is of similar magnitude as in the Brazil Current region, annual mean values amounting to 42,16 , and $30 \mathrm{~W} \mathrm{~m}^{-2}$, respectively.
\end{abstract}

\section{Introduction}

The huge anticyclonic gyres, with equatorward flowing cold waters in the eastern and poleward directed warm currents in the western part of the oceans, are generally regarded as major factors in the large-scale climatic pattern. Contrasts in the heat budget between the waters off the east and west coasts of the continents are also suggested by Budyko's (1963) maps. However, a quantitative assessment of zonal asymmetries in the oceanic heat budget does not seem to have been attempted as yet. Long-term ship observations that have recently become available provide an adequate data base for this purpose.

\section{Data}

More than seven million individual ship observations taken over the tropical Atlantic and eastern Pacific during 1911-70 were obtained from the National Climatic Center at Asheville, North Carolina, and compiled into a climatic atlas (Hastenrath and Lamb, 1977), with data being processed by one degree square areas. An atlas of the oceanic heat budget, based on the same data, and containing monthly and annual maps of the key budget terms, is in preparation.

\section{Basic theory}

The heat budget equation for the oceanic water body can in approximate form be written:

$$
S W \uparrow \downarrow+L W \uparrow \downarrow=Q_{s}+Q_{e}+\left(Q_{v}+Q_{t}\right)
$$

The left-hand terms are net shortwave and longwave radiation at the ocean surface, and the right-hand terms denote sensible and latent heat flux at the sea-air interface, heat export and storage within the ocean, respectively.

For the computation of net shortwave radiation $S W \uparrow \downarrow$ a variety of empirical formulae has been suggested (e.g. Budkyo, 1958), using total cloudiness and latitude as input. In the present study use was made of the theoretical framework presented by Bernhardt and Philipps (1958). Preference was given to Bernhardt and Philipps' (1958) over Budyko's (1958) method, because it allows for spatial variation of water vapor turbidity and would account for varying dust turbidity as pertinent information may become available. For comparison both procedures were applied to actual data, with the following results. Global radiation at cloudless sky computed from the Bernhardt and Philipps method is by about $15 \mathrm{~W} \mathrm{~m}^{-2}$ smaller than Budyko's latitude-mean 
tabulation. However, variations along a latitude circle resulting from the humidity pattern are of the same magnitude, but are ignored by the Budyko procedure. For global radiation at actual cloud cover, Bernhardt and Philipps' method yields values only about $5-10 \mathrm{~W} \mathrm{~m}^{-2}$, or a few percent, smaller than Budyko's procedure: Budyko uses a somewhat stronger reduction of radiation due to cloudiness. Both methods assume the same value for the albedo of the ocean surface. Consequently maps of net shortwave radiation at actual cloud cover differ by a few percent. This is well within the uncertainty of either method.

Net longwave radiation was computed from Brunt's formula (Budyko, 1958):

$$
\begin{aligned}
& L W \uparrow \downarrow=\varepsilon \sigma T^{4} w(0.39-0.056 \sqrt{q})\left(1-0.53 C^{2} T\right) \\
& +4 \varepsilon \sigma T^{3} w\left(T_{w}-T_{a}\right)
\end{aligned}
$$

sea surface temperature $T_{w}$ and air temperature $T_{a}$ being in degrees $K$, and surface specific humidity $q$ in $\mathrm{gm} / \mathrm{kg}$, emissivity $\varepsilon=1$ and StefanBoltzmann's constant $\sigma=567 \times 10^{-10} \mathrm{~W} \mathrm{~m}^{-2} K^{-4}$.

Sensible and latent heat flux were calculated from the bulk-aerodynamic equations:

$$
\begin{aligned}
& Q_{s}=\rho C_{D} c_{p}\left(T_{w}-T_{a}\right) V \\
& Q_{e}=\rho C_{D} L\left(q_{w}-q_{a}\right) V
\end{aligned}
$$

Values of $\rho=1.175 \mathrm{~kg} \mathrm{~m}^{-3}$ and $C_{D}=1.4 \times 10^{-3}$ were used for air density and drag coefficient, respectively. $c_{p}$ is specific heat at constant pressure and $L$ latent heat of evaporation. The saturation specific humidity corresponding to the sea surface temperature $T_{w}$ was computed for $q_{w}$, with reference to a salinity of 35 per mille; and scalar mean wind speed was used for $V$.

Of the observational data mentioned in section 2 , the following elements thus served as input to the heat budget calculations: total cloudiness, dew point, and pressure, for $S W \uparrow \downarrow$; sea surface and air temperature, dew point, pressure, and cloudiness for $L W \uparrow \downarrow$; sea surface and air temperature, dew point, pressure, and scalar wind speed for $Q_{s}$ and $Q_{e}$.

Time-averaged data were used in the present calculations. Covariance between elements can make the product of averages differ from the average of products, and $C_{D}$ depends on stability (Bunker, 1976; Bunker and Worthington, 1976). However, these effects may be of subordinate importance for the low-latitude oceans mapped here. In fact, Bunker's (1976) annual maps of $Q_{e}$ and $Q_{s}$ for the North Atlantic are rather similar to the present charts: only in limited areas are his figures of $Q_{e}$ by about $15 \mathrm{~W} \mathrm{~m}^{-2}$ larger than the present ones, a difference of about ten percent. However, Bunker's (1976) values of net radiation $S W L W \uparrow \downarrow$, calculated from somewhat different empirical formulae, are systematically larger than in Fig. 1. Consequently, his residual $\left(Q_{v}+Q_{t}\right)$ differs from Fig. 4 towards larger positive values. Within the error limits of calculation methods this could be accounted for by a smaller emissivity and somewhat different coefficients in Eq. (2). The coarse grid of Budyko's (1963) charts, as discussed by Bunker and Worthington (1976), precludes a meaningful comparison of spatial patterns. In the present study, annual maps of heat budget components were constructed from the sets of twelve monthly computations. All maps were machine-isoplethed and then re-drawn by hand.

\section{Spatial pattern}

The annual mean of net radiation $S W L W \downarrow \uparrow$ at the ocean surface is mapped in Fig. 1. In addition to the broad latitudinal control the pattern is largely dictated by cloudiness. In particular the realm of the cold Benguela and Humboldt Currents, off the west coasts of Africa and South America is characterized by more abundant cloud cover and reduced net radiation as compared to the western Atlantic.

Sensible heat flux $Q_{s}$, Fig. 2, plays a subordinate role in the heat budget of the tropical oceans. The cold ocean currents off the west coasts stand out as regions of downward directed flux, contrasting with largest exchange from ocean to atmosphere in the domain of the warm currents.

The pattern of latent heat flux $Q_{e}$, Fig. 3, is likewise predominantly controlled by sea-air temperature difference: smallest values are found in the cold water regions, whereas the flux reaches more sizable proportions in the domain of the poleward flowing Brazil and especially the Gulf Stream Current systems.

Fig. 4 depicts the residual sum of the divergence of heat transport and storage within the oceanic water body, $\left(Q_{v}+Q_{t}\right)$. For the year as a whole this essentially represents the lateral export/import of heat $Q v$. Energy export is indicated for much of the low-latitude ocean with a broad decrease poleward. More conspicuous, however, is the zonal contrast between export from the Canary and import into the Gulf Stream region. Proceeding from the coasts of Peru-Chile and Southwest Africa towards the open ocean, $Q v$ changes rather abruptly from large export to import. Differences between these west coast 


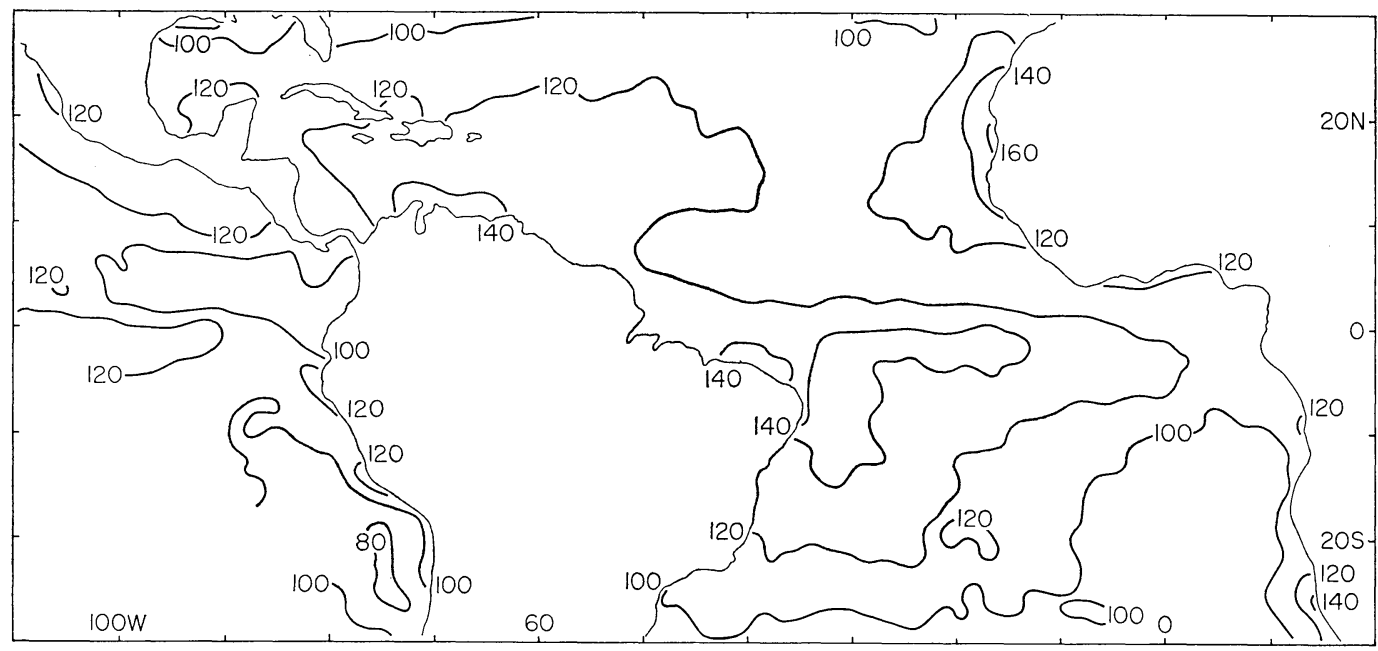

Fig. 1 Annual mean net radiation of the ocean surface, $S W L W \uparrow \downarrow$ in $\mathrm{W} \mathrm{m}^{-2}$.

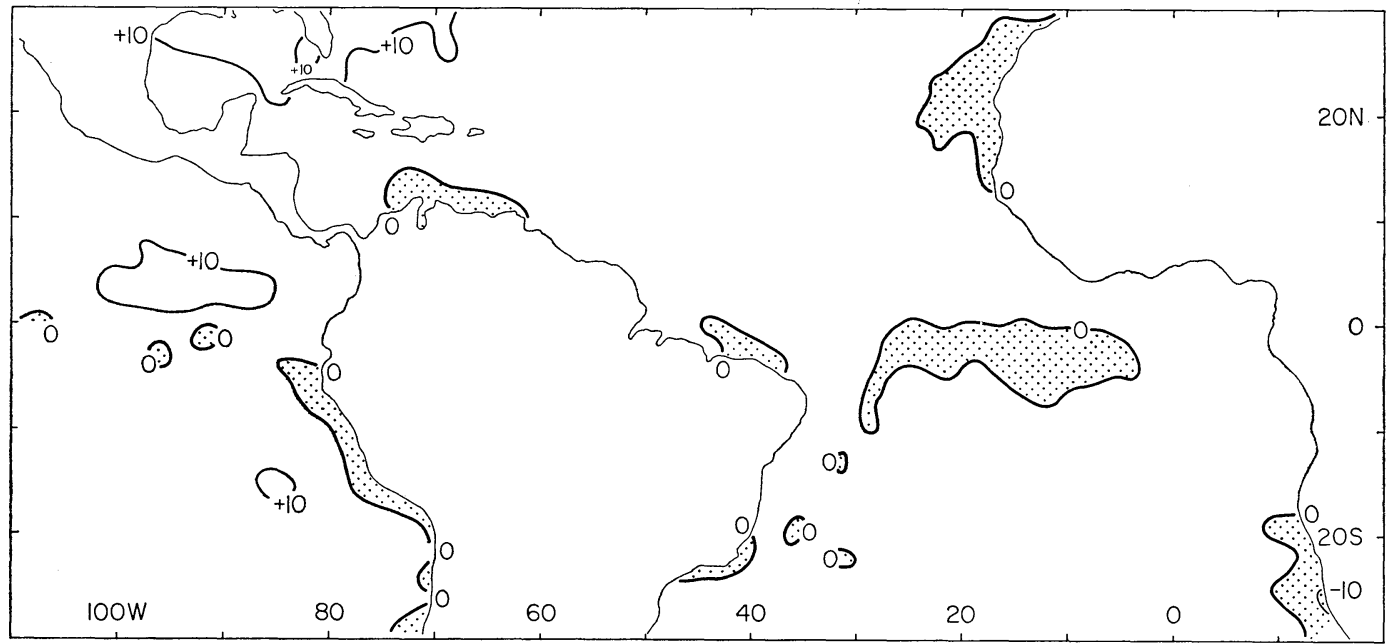

Fig. 2 Annual mean of sensible heat flux, $Q_{S}$, in $\mathrm{W} \mathrm{m}-2$. Dot roster denotes areas of downward directed heat flux.

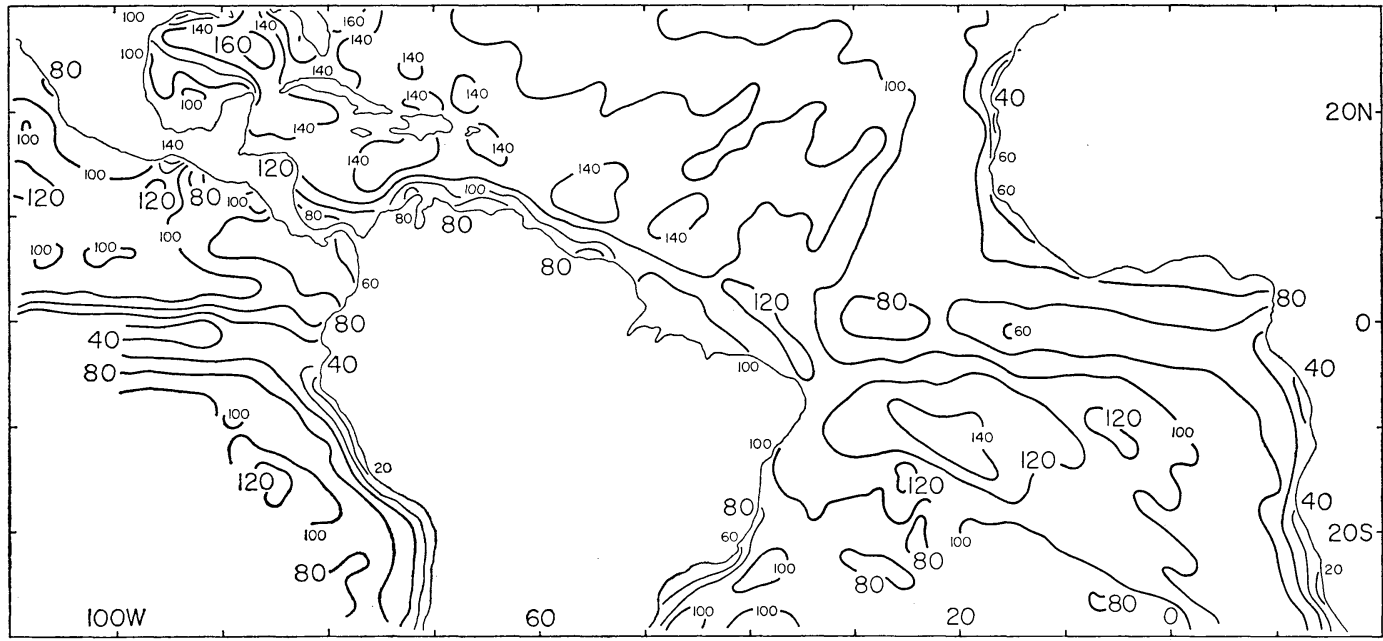

Fig. 3 Annual mean of latent heat flux, $Q_{e}$, in $\mathrm{W} \mathrm{m}{ }^{-2}$. 


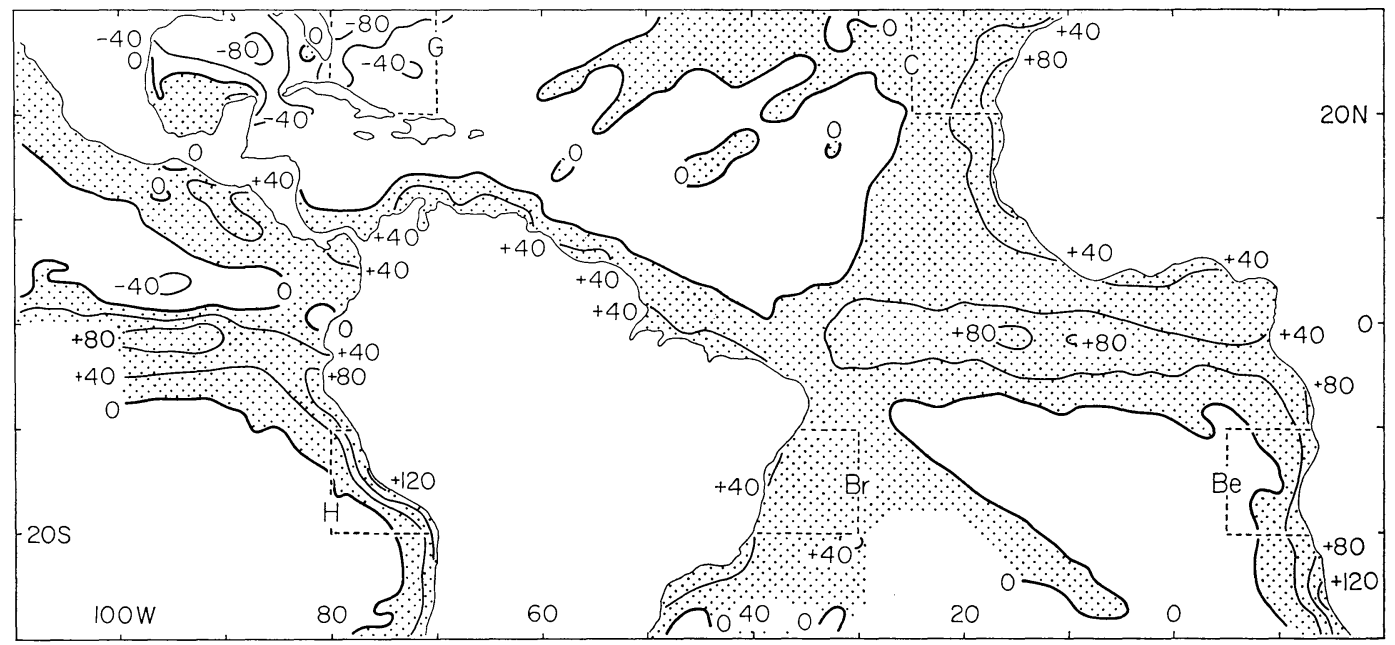

Fig. 4 Annual mean of divergence of heat transport and storage within the ocean, $\left(Q_{v}+Q_{t}\right)$, obtained as residual, in $\mathrm{W} \mathrm{m}^{-2}$. Dot roster denotes areas of heat export. Dotted rectangles marked $\mathrm{G}, \mathrm{C}, \mathrm{H}, \mathrm{Br}$, and $\mathrm{Be}$ indicate areas referred to in Figs. 5-9.

regions and the domain of the Brazil Current are not prominent: in fact, reduced net radiation and small latent and sensible heat fluxes off the west coasts-as compared to the western part of the oceans-largely offset each other.

\section{Seasonal march}

The annual variation of the major heat budget components is in Figs. 5-9 displayed for the representative sea areas identified in Fig. 4.

Figs. 6 and 5 compare blocks at the same latitude in the domains of the Canary and Gulf Stream systems. Net radiation differs little between the two areas, but latent and sensible heat flux is much smaller in the Canary Current region. Accordingly, a sizable energy residual is left for export to other parts of the globe, especially in summer. By contrast, the Gulf Stream region has to import large quantities of heat to meet its large latent and sensible heat expenditures particularly during winter.

Figs. 7-9 depict the seasonal march of oceanic heat budget components in the cold Humboldt and Benguela and the warm Brazil Current regions. As a consequence of the extended cloudiness net radiation is much smaller off the coasts of Peru and Chile (Fig. 7) and Southwest Africa (Fig. 9) than along the Atlantic coast of South Africa (Fig. 8). Also the annual variation is similar. Sensible heat flux is small in all three areas, but latent heat flux is much larger in the warm Brazil Current domain (Fig. 8) than in the two west coast regions. The annual range of latent heat flux is moderate in all three blocks.

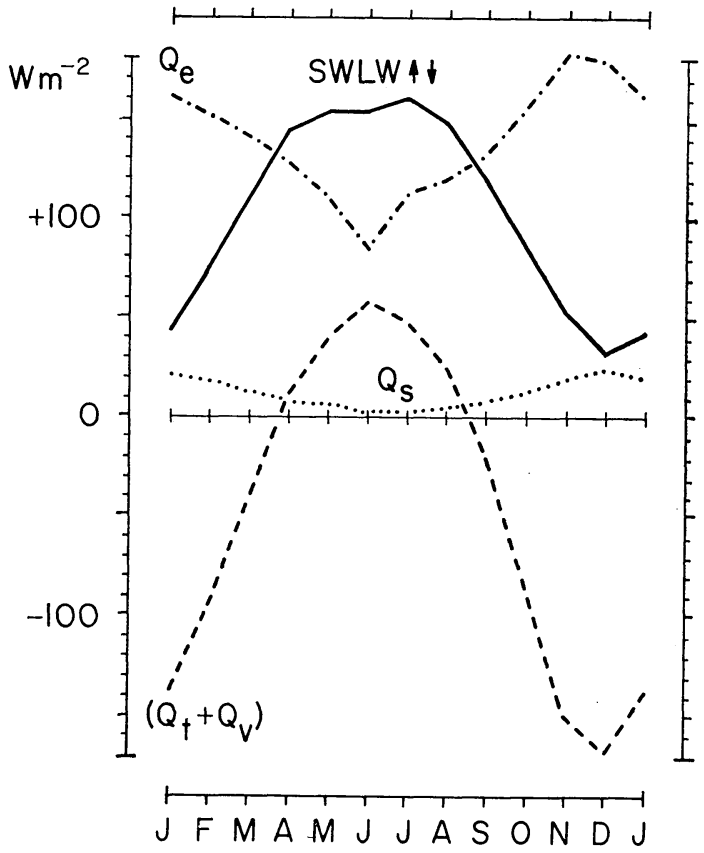

Fig. 5 Gulf Stream. Seasonal march of heat budget components. Solid, dotted, dash-dotted, and broken lines denote net radiation $(S W L W \uparrow \downarrow)$, sensible $Q_{S}$ and latent heat flux $Q_{e}$, and the sum of divergence of heat transport and storage within the oceanic water body, $\left(Q_{v}+Q_{t}\right)$, obtained as residual. 


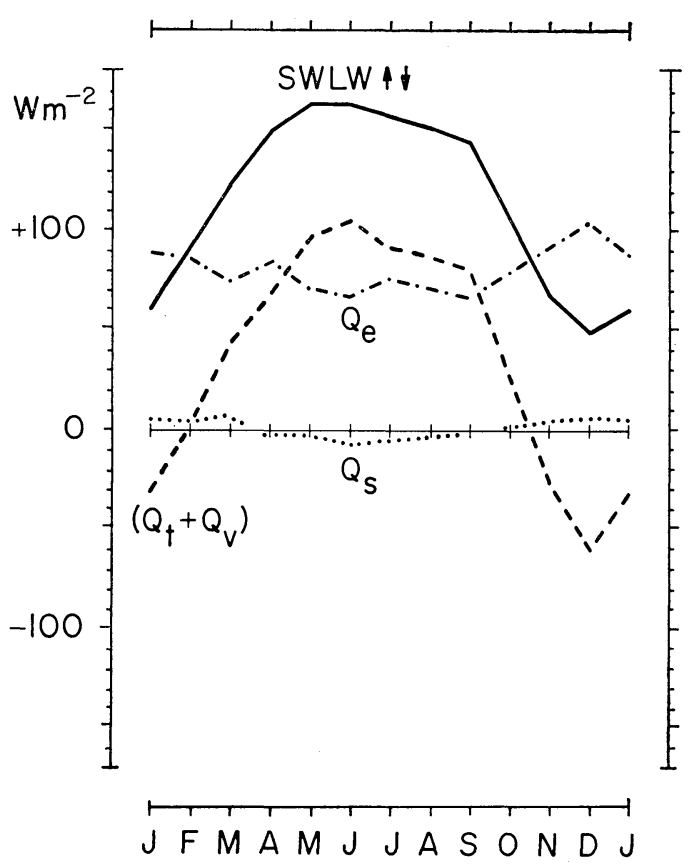

Fig. 6 Canary Current. Seasonal march of heat budget components. Symbols as in Fig. 5.

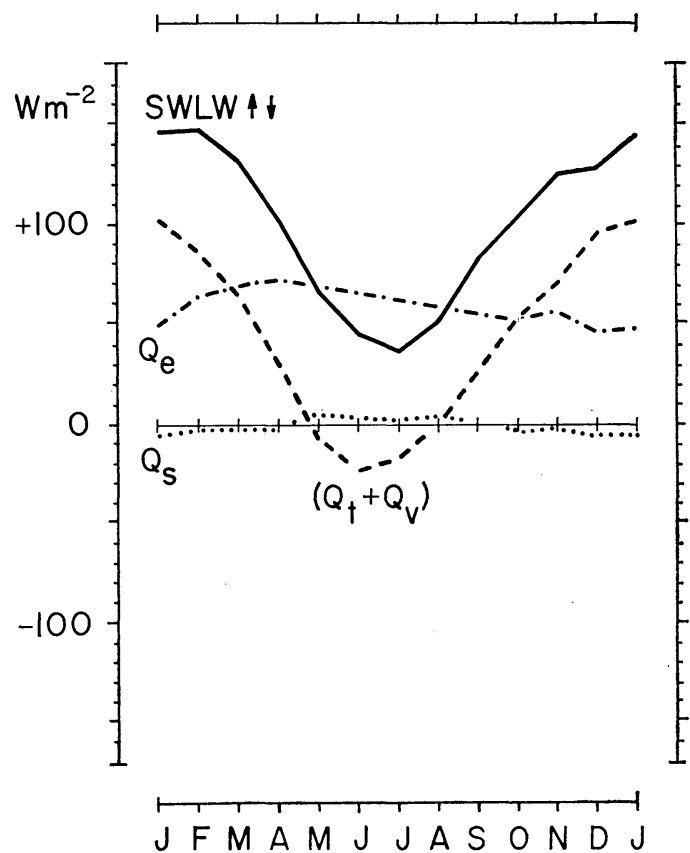

Fig. 7 Humboldt Current. Seasonal march of heat budget components. Symbols as in Figs. 5 and 6.

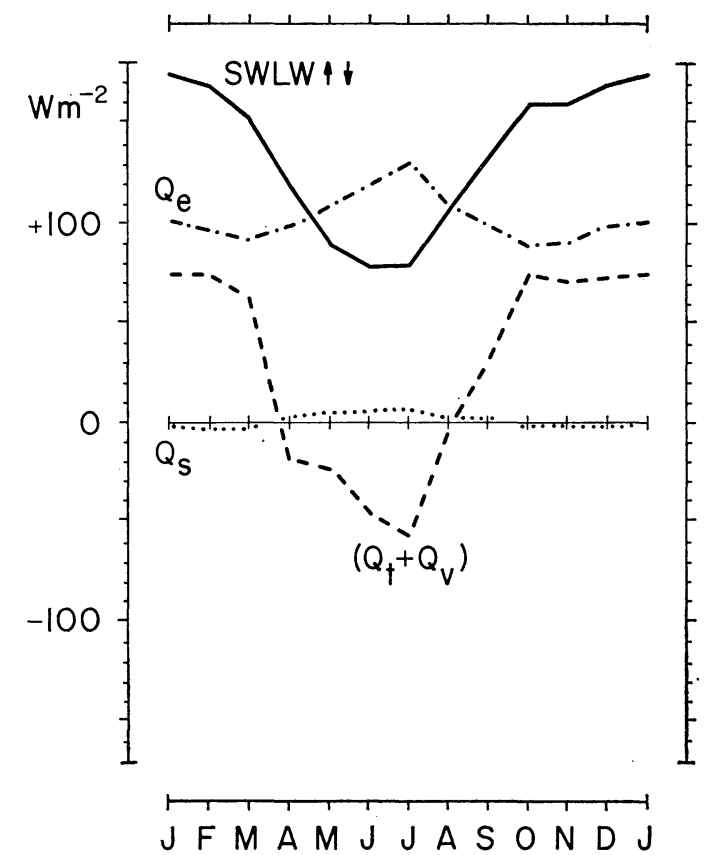

Fig. 8 Brazil Current. Seasonal march of heat budget components. Symbols as in Figs. 5-7.

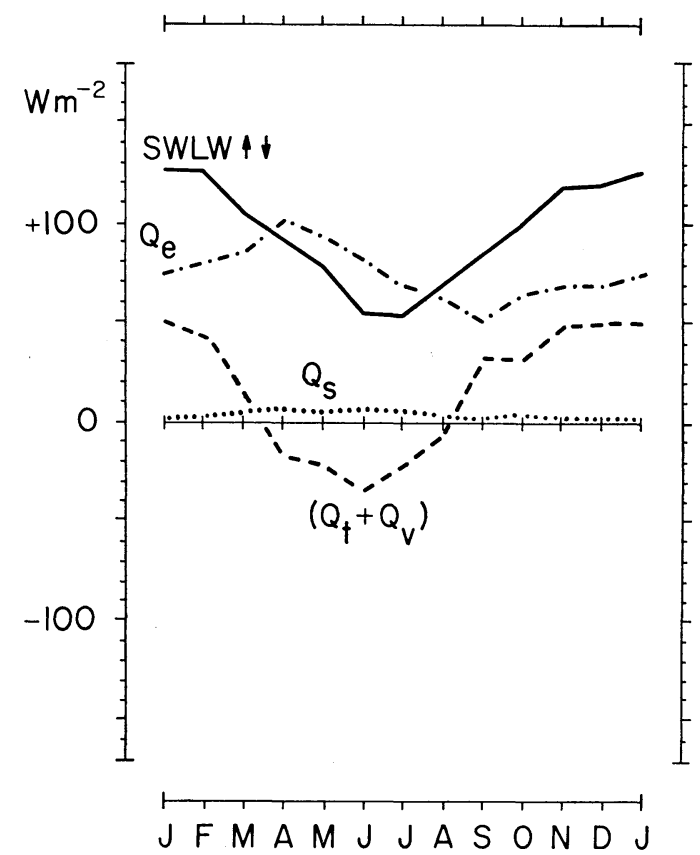

Fig. 9 Benguela Current. Seasonal march of heat budget components. Symbols as in Figs. 5-8. 
A large residual is left for heat export and for storage within the oceanic water body in all three regions, with largest values in southern summer. For the year as a whole, the ocean exports heat from all three areas. Zonal differences in net radiation and latent heat flux partly counterbalance each other, resulting in little contrast for the residual heat export.

\section{Concluding remarks}

Data available in the present study permitted a mapping of the oceanic heat budget in appreciable spatial detail, and characteristics of seasonal variations could be adequately assessed for selected sea areas. The heat budget is basic to the climatic asymmetry between the western and eastern portions of the low-latitude oceans.

Extended cloud cover accounts for reduced net radiation off the coasts of Peru-Chile and Southwest Africa as compared to the western South Atlantic. Zonal differences in cloudiness and net radiation between the Canary and Gulf Stream regions are less pronounced. Comparatively small sea-air temperature differences in the realm of the equatorward directed Canary, Benguela, and Humboldt Current systems, greatly reduce the heat expenditure for evaporation. Accordingly, a large portion of the annual net radiative heat gain in these areas is disposed of within the oceanic water body, namely 39, 16, and $42 \mathrm{~W} \mathrm{~m}^{-2}$, respectively. This compares with an oceanic export of $30 \mathrm{~W} \mathrm{~m}^{-2}$ in the Brazil Current region, and a heat import of $43 \mathrm{~W} \mathrm{~m}^{-2}$ in the Gulf Stream domain. The contrast in oceanic heat budget characteristics between the Canary and Gulf Stream systems is particularly spectacular.

\section{Acknowledgments}

This study was supported by the Climate Dynamics Research Program of the National Science Foundation. P. Lamb and P. Guetter did the computer programming.

\section{References}

Bernhardt, F., Philipps, H., 1958: Die räumliche und zeitliche Verteilung der Einstrahlung, der Ausstrahlung, und der Strahlungsbilanz im Meeresniveau. I. Die Einstrahlung. Abhandlungen Meteorol. Hydrol. Dienst. DDR, No. 45, Akademie-Verlag Berlin, $227 \mathrm{pp}$.

Budyko, M. I., 1958: The heat balance of the Earth's surface. English translation by U.S. Weather Bureau, Washington, D.C.

, 1963: Atlas of the heat balance of the Earth. (in Russian), Kartfabrika Gosgeoltehizdata, Leningrad.

Bunker, A., 1976: Computations of surface energy flux and annual sea-air interaction cycles of the North Atlantic Ocean. Mo. Wea. Rev., 104, 1122-1140.

- Worthington, L. V., 1976: Energy exchange charts of the North Atlantic Ocean. Bull. Amer. Meteor. Soc., 57, 670-678.

Hastenrath, S., Lamb, P., 1977: Climatic atlas of the Tropical Atlantic and Eastern Pacific Oceans. University of Wisconsin Press.

\title{
熱帯海洋の熱収支における東西の非対称について
}

\author{
ステファン・ハステンラス \\ ウィスコンシン大学, ウィスコンシン州, 米国
}

海洋の熱収支を1911ー70年間の熱帯の大西洋と東太平洋における船船観測デーカかららつら行われている方法で計 算した。海洋の東部と西部のあいだの東西の非対称を暖いメキシコ湾流とブラジル海流および彾いカナリー・ベンゲ ラ[南西アフリカ沖], フンボルト[ペルー, チリ沖]海流の領域を例にとって調べた。同じ緯度帯について，カナリ 一海流は比較的小さな潜熱フラックス风ోもち地球の他の部分に年平均で $39 \mathrm{Wm}^{-2}$ のエネルギーを輸出するが，これ はメキシコ湾流域での $43 \mathrm{~W} \mathrm{~m}^{-2}$ の輸入に匹敵する。ペルー, チリ沖と南西アフリカ沖では, 放射の純量は広大な雲 域により減少し，潜・顕熱フラックスも比䡆的小さいが，残差としてえられる海洋水本体内での熱輸出はブラジル海 流域に拈けるものと同程度の大きさを持ち，年平均值はそれぞれ $42 ， 16$ および $30 \mathrm{Wm}^{-2}$ になる。 